\title{
Disarticulation and the Crisis of Neoliberalism in the United States
}

\section{David Jaffee}

University of North Florida, USA

\begin{abstract}
Neoliberal policies instituted since the 1980s have transformed the United States economy in ways that have produced serious structural distortions in the basic operation of capitalism. Using Samir Amin's concept of disarticulation, previously applied exclusively to the periphery of the world economy, this article argues that the twin and mutually reinforcing features of neoliberalism - global corporate restructuring and financialization - have now generated disarticulation in the core nations. This disarticulated structure is responsible for the economic stagnation and sharply unequal income/wealth distributional outcomes that characterize contemporary U.S. capitalism.
\end{abstract}

\section{Keywords}

disarticulation, economic crisis, financialization, globalization, neoliberalism, political economy, stagnation

\section{Introduction}

In 1976, Samir Amin wrote his classic work Uneven Development: An Essay on the Social Formations of Peripheral Capitalism. It represented a hybrid neo-Marxian analysis of global capitalism combining conceptual insights from dependency and world-systems theory. While prior critical analyses of development and underdevelopment outlined the socio-economic processes that transferred surplus from the peripheral satellites to the core center states of the metropolis, Amin focused more directly on the distinctive capitalist social formations in the two global regions that could explain both their internal dynamics and external orientations.

He described capitalism in the center states as autocentric capitalism and the capitalism in the periphery as extraverted capitalism. The terms were meant to denote the fact that center states could generate internally the necessary conditions for capital accumulation - the capacity to produce (supply-side) and the capacity to consume (demand-side) - while peripheral states were characterized by extraverted accumulation that was outward-looking, export-oriented, and dependent 
upon economic activity in the center states. Importantly, these differential forms of capitalism identified by Amin were the historical product of colonial relations between the core and periphery and, in that sense, the autocentric form was not entirely self-sustaining as it depended upon the peripheral export structure through systems of unequal and asymmetric exchange.

Amin (1976: 202) first mentions disarticulation in the context of the unique peripheral social formation as that "which prevents the transmission of the benefits of economic progress from the poles of development to the economy as a whole." More specifically, in peripheral nations, as a result of the historical relation of colonialism and transnational investment, there are weak internal linkages between domestic economic activities and sectors:

The consequences that follow from this disarticulation are crucial. In a structured autocentric economy, any progress that begins at any point is spread throughout the entire organism by many convergent mechanisms [...] If the economy is extraverted, all these effects are limited, being largely transferred abroad [...] The underdeveloped economy is made up of sectors, of firms that are juxtaposed and not highly integrated among themselves, but are each of them strongly integrated into entities the centers of gravity of which lie in the centers of the capitalist world. (Amin, 1976: 237-38)

In the ideal type, properly working, autocentric accumulation model, based largely on the Keynesian virtuous cycle, the two requisite capacities - to produce and to consume - are in relative balance as profits are plowed into new forms of production generating employment and income (the multiplier) and, in turn, income is directed toward consumption further stimulating investment (the accelerator), and the cycle continues. However, as a Marxist, Amin notes the contradiction between the capacity to produce and the capacity to consume as a source of economic crisis in the autocentric model. The source of this contradiction is often centered on the role of wages and the fact that the capacity to produce is enhanced by low wages (low costs of production generally) while the capacity to consume is enhanced by higher wages directed toward effective demand. Socio-economic and political factors pushing wages in one direction or another (yielding a "profit squeeze" or a "wage squeeze"), driven by the relative power of labor and capital, constitute the basis for one neo-Marxian crisis theory. When the capitalist class is most powerful, the capacity to produce is strong and the capacity to consume is weak producing a demand-side or underconsumption crisis. When labor is relatively strong, the capacity to produce is weaker and the capacity to consume stronger, provoking a supply side crisis (Bowles et al., 1990). But in an extraverted export-oriented social formation the capacity to consume does not depend upon the wages of domestic workers since the products produced are consumed elsewhere and thus there is no necessary linkage.

It was de Janvry (1981) who advanced significantly the conceptual formulation and analysis of the disarticulated social formations in the peripheral nations and made the important distinction between social and sectoral disarticulation. Under social disarticulation, as described above, the relationship between the return to labor and the return to capital is short-circuited as the goods produced in the peripheral nation are export-oriented and destined for the consumer markets in the core. Wages are a pure cost. The domestic working population does not serve as the market for the goods they produce. The capacity to produce profitably does not depend upon the capacity to consume domestically. Thus, the virtuous cycle of autocentric capitalism does not exist in this extraverted social formation.

Under sectoral disarticulation, the positive connections and spinoff effects between economic sectors is largely absent as a result of the extraverted social formation. To take one example, a nation that possesses mineral resources might, ideally, develop a capital goods sector to supply the technology and machinery for the extraction of minerals. This is the backward linkage. A forward 
linkage would be from the extraction to a mineral processing/manufacturing sector. Under the extraverted disarticulated social formation, however, the capital goods are imported from the core and the raw minerals are exported for processing in the core. In this way the domestic economy does not benefit from the existence of the raw material sector as they would if there was sectoral articulation. The raw material sector is unable to induce the linkages suggested by imbalanced growth models of development (see Hirschman, 1958).

\section{Neoliberalism and Disarticulation}

We can now turn to the developments that have generated comparable forms of disarticulation in what were described by Amin as the autocentric capitalist states of the core. The place to begin is the economic crisis of the 1970s in the United States and the corporate restructuring that occurred under neoliberalism.

Most observers identify the mid-1970s as the point at which the Keynesian post-WWII political economic model, on which the autocentric capitalist concept is based, entered a crisis phase. This "social structure of accumulation" responsible for the post-WWII phase of capital accumulation is sometimes referred to as the "capital-labor accord" to denote that capital and labor had come to a mutual agreement on the distribution of the surplus where capital acknowledged the importance of the capacity to consume for the realization of profit (Gordon et al., 1982). Higher wages were considered both a cost and also a benefit which allowed for a non-zero-sum logic to prevail. But in the 1970 s this began to unravel as the U.S. economy experienced stagflation, and capital began to disinvest based on the following litany of complaints: taxes too high, labor too strong, regulations too stifling, and welfare too generous. The profit squeeze associated with these deepening Keynesian conditions and policies, along with increasing international competition from Europe and Japan, prompted a backlash against the "capital-labor" accord. One can think of Reaganomics, supply-side economics and, ultimately, neoliberalism as the political economic policy response to remedy the perceived disincentives to capital investment aimed at reestablishing conditions for corporate profitability and competitiveness. There was a two-pronged approach to crisis resolution under the emerging neoliberal model - corporate restructuring and the use of finance to restore profitability. They have been mutually reinforcing. Under this emerging neoliberal regime - what became the new "social structure of accumulation" - there was both the policy response by the state and a strategic restructuring by American corporations.

\section{Corporate Restructuring}

American corporations pursued restructuring strategies that deviated from past practices. The two key elements were structural disintegration and spatial dispersion (Jaffee, 2001), more commonly known as outsourcing and offshoring, respectively. At one time corporations followed a strategy of vertical integration involving the formal ownership and control of backstream suppliers and upstream dealers of their products. This logic was replaced by an emphasis on reducing physical asset ownership, focusing on core competencies, enhancing flexibility, and establishing a mean and lean corporation (Lichtenstein, 2014; Weil, 2014).

The so-called "Nikefication" of the American corporation (see Davis, 2016) involved outsourcing and subcontracting the production and manufacturing to foreign firms while retaining the design, marketing, and branding functions. Nike epitomized this model but it soon came to dominate the corporate landscape. The resulting "hollow" or "virtual" corporation employs far fewer workers and in most cases no longer owns or invests in production facilities either domestically or abroad. As we shall see, these two facts have enormous macroeconomic consequences. 
Similarly, the largest retailers, such as Walmart and Target, stock their shelves with products almost exclusively manufactured offshore, largely in China, and conform to the "buyer-driven commodity chain" (Gereffi, 1994) or mercantilist model that pulls cheaply produced goods from subcontractors, made to specification, through the supply chain. These various patterns of the global reorganization of production now fall under the larger heading of "global value chains" (GVC). A GVC is one way to describe "the full range of activities which are required to bring a product or service from conception, through the different phases of production (involving a combination of physical transformation and the input of various producer services), delivery to final consumers, and final disposal after use" (Kaplinsky and Morris, 2001: 4) that usually entails outsourcing and/or offshoring. These chains are driven by either large retail "buyers" who exercise monopsony power over subcontractors, with Walmart as the prototype, or "brand manufacturers" who subcontract production and then slap a brand label on the final product elevating its value and marketability, with Apple being a prominent example. These "lead firms" such as Walmart, Nike, or Apple manage or govern the dispersed set of economic activities from conception to final end use. Most significantly, what was once done within a single firm (vertically integrated) domestically, is now carried out by legally independent entities offshore in Asia or Latin America.

On the offshoring dimension of the process, it is worth returning to the central contradiction between the capacity to produce (enhanced by low wages) and the capacity to consume (enhanced by high wages) to understand how this contradiction not only contributed to the profit squeeze, capital strike, and the supply-side crisis of the 1970s, but also served to fuel globalization strategies under deregulatory policies encouraging capital mobility. When viewed as a strategy to resolve the contradiction, this "spatial fix" (Harvey, 1982) exploits geographic variations in business climate conditions prompting corporations to relocate and restructure production to enhance the capacity to produce and restore profitable conditions of production in low wage, unregulated environments. When this involves offshoring to cheap labor sites, the capacity to produce and the capacity to consume are geographically segregated with the latter satisfied by returning the cheaply produced goods to the center state where the wage levels are sufficient to support demand. As we shall see, this strategy had its own built-in contradictions as offshoring would inevitably undermine, over time, the domestic capacity to consume in the center states through job loss and the expansion of a global labor market.

Thus, when one of the defining characteristics of the autocentric articulated social formation - that is, the mutually reinforcing relationship between the capacity to consume and the capacity to produce - begins to favor labor and the capacity to consume, the subsequent contradiction is resolved through corporate strategies that will eventually undermine the autocentric model and contribute directly to the emergence of new forms of disarticulation in the center states. Those who produce the goods in the periphery are not those who consume them; and those who consume the goods in the core are not those who produce them. The latter is no less a form of disarticulation and a deviation from the autocentric model than the former. As well-paying manufacturing jobs are shifted abroad, income-generating opportunities in the core are diminished and thus the market for the imported goods is potentially threatened if there is no compensating income increment propping up the capacity to consume. It is here where we can see the expanding role of the financial sector.

\section{Financialization}

One of the consequences of disarticulation in the peripheral nations was what Amin termed the "hypertrophy of the tertiary." This referred to the outsized expansion of the service sector of the economy far beyond what one would expect given the level of economic development or 
industrialization. As Amin (1976: 245) explained for the extraverted economies of the Third World, "competition by the industries of the dominant centers prevents the local capital that is accumulated from making its way into investment in industry, and diverts this capital into complementary activities connected with the export economy, especially commerce." The hypertrophy of the tertiary is driven by the uninvested income generated in the landowning sector. Amin further elaborates that

In the periphery $[\ldots]$ the intensification of external exchanges - in the framework of a specialization based at the outset upon the export of agricultural produce - has strengthened the predominance of ground rent wherever an unequal distribution of landownership, either preexistent or arising as a consequence of the commercialization of production, has made this possible. Now, ground rent does not necessarily have to be saved, as profit on capital must be, in order to be invested in the modernization that competition makes necessary, for it is an income derived from monopoly, and can therefore be spent in its entirety. Such spending is luxury expenditure that is focused, so far as material goods are concerned, upon imported goods and, so far as local products are concerned, upon services (servants, leisure services, etc.). (1976: 246)

Amin employs the concept of "hoarding" to denote concentration of income and the failure to reinvest in domestic production and the "social fact that the dominant classes appropriate the surplus in a setting in which they are not at all obliged to invest a saving in order to guarantee their future income" and further, in the extraverted peripheral economy, "profits on invested capital are to a large extent exported, since this capital is foreign-owned" (1976: 235-36)

Today in the center states, and most particularly in the United States, we have what has been described as the "hypertrophy of the financial sector" (Greenwood and Scharfstein, 2013; Krippner, 2005; Marens, 2003). The parallels to the extraverted hypertrophy of the periphery described by Amin are striking. A corporate sector with monopoly or oligopolistic power deriving profits and rents from that market position, but not reinvesting in domestic physical innovative production or capital formation, diverts that income into the financial sector. This addresses and explains the widely-reported "mysterious divergence" between corporate profits and net capital investment (Harding, 2013).

In associating the hypertrophy of finance with the rise of the neoliberal model, it is significant that conceptually and empirically financialization is best understood and defined as "accumulation-centered" (rather than "activity-centered") and based on where profits are generated (Krippner, 2011). This suggests first that the financialization was a response to an accumulation crisis rather than an employment crisis with the state playing an active role in facilitating this shift in profit generation:

the turn to finance allowed the state to avoid a series of economic, social, and political dilemmas that confronted policymakers beginning in the late 1960s and 1970s, paradoxically preparing the ground for our own era of financial manias, panics, and crashes some three decades later [...] Thus financialization was not a deliberate outcome sought by policymakers but rather an inadvertent result of the state's attempts to solve other problems. (Krippner, 2011:2)

Second, in measuring financialization empirically, Krippner (2011) uses the proportion of corporate profits generated by the financial sector (FIRE: finance, insurance, and real estate). Others have documented additional activities that have contributed to the expansion of the financial sector. Most notable are asset management costs and credit intermediation especially as it pertains to household credit (Greenwood and Scharfstein, 2013).

Krippner's (2011) analysis is consistent with the perspective of the Monthly Review School advancing the "stagnation thesis" of capitalist accumulation and crisis (originally Baran and Sweezy, 1966; today Foster and McChesney, 2012). In this view, the crisis tendency under monopoly-finance 
capital is toward over-accumulation and stagnation without the continual development and discovery of new outlets for the accumulated surplus. Thus, in this analysis, financialization is a symptom of stagnation tendencies, representing a potential "fix" and profitable outlet for the accumulated and concentrated surplus.

There is also an important and critical mutually reinforcing dynamic between financialization and corporate restructuring. Downsizing, outsourcing, and offshoring became the corporate strategies that were highly rewarded by Wall Street. Lazonick (2013a) has carefully outlined how three aspects of corporate restructuring - rationalization (plant closings), marketization (no longer careers for life in corporations), and globalization (offshoring and resulting worker vulnerability) - have been aided and abetted by the concomitant shift toward a financial model of the firm (see Fligstein, 1993), with primary allegiance to shareholders and shareholder value (Lazonick and O'Sullivan, 2000). This further incentivized the downsizing and outsourcing activity. Lazonick (2014) also notes the corresponding shift from a corporate strategy based on a "retain-and-reinvest" to a "downsize-and-distribute" approach calculating that for the decade 2003-2012, the 449 companies publicly listed in the S\&P 500 index spent only $9 \%$ of their earnings on new capital investment. They used 54\% to buy back their own stock, and 37\% to pay dividends. Further, consistent with the finance-based conception of the firm - the corporation is increasingly viewed not as an economic entity generating value through production, but rather as an asset that retains and enhances its market value through financial strategies (Appelbaum and Batt, 2014).

Hudson's (2016: 24) study of the finance and debt economy contrasts the "real economy" of production and consumption, based on the employment of labor, tangible means of production and technological potential" with the "debt and ownership" economy "that transforms its economic gains into political control to enforce payments of debt and to preserve property and natural resource or monopoly rent privileges." The latter constitutes, in Hudson's analysis, a rentier economy that classical political economics deemed most destructive to the prosperity of the general population.

The two structural threads of the United States neoliberal political economy outlined above are most effectively tied together in Milberg and Winkler's (2013) theoretical and empirical analysis of globalization which, they argue, represents:

A shift in corporate strategy, involving a search for lower costs and greater flexibility [...] and a desire to focus on core activities and allocate more resources to financial activity and short-run shareholder value $[\ldots]$ while reducing commitments to long-term employment and job security [...] offshoring has given firms the chance to raise profits while keeping price increases low by reducing costs, raising flexibility, offloading risks, and occasionally bypassing labor and environmental regulation, all while retaining rents from design, marketing, and financial activity. (Milberg and Winkler, 2013: 12)

We can now consider how these structural features have impacted larger macroeconomic conditions in the U.S.

\section{Disarticulation and Stagnation}

The evidence for the corporate restructuring and financialization of the U.S. economy is overwhelming. We can now turn to the question of whether these twin features of U.S. neoliberalism operate as disarticulating maladies that portend sustained stagnation. The logic of the argument is illustrated in the two diagrams below. Figure 1 depicts the virtuous autocentric cycle in which a capacity to produce (CTP) exists through investment in production and the capacity to consume (CTC) is realized through the labor income deriving from the productive investment. The 


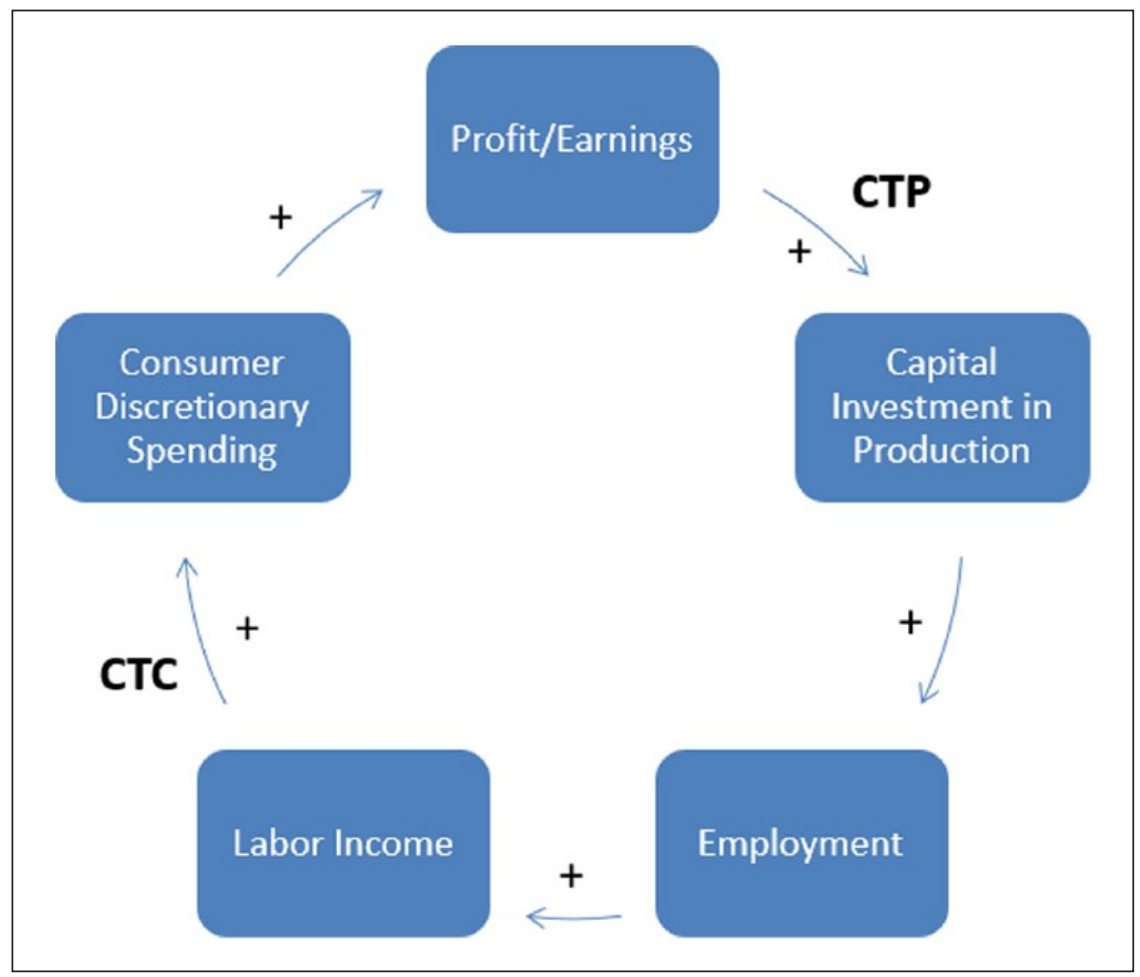

Figure I. The virtuous autocentric cycle.

multiplier and accelerator are both operating. Figure 2 depicts the consequences of the neoliberal model in which the hypertrophy of the financial sector and the corporate restructuring through outsourcing/offshoring short-circuit the critical and necessary connections and conditions supporting the CTP and the CTC.

What empirical evidence exists to support the model in Figure 2 that assumes the diversions will contribute to sustained economic stagnation?

\section{Disarticulation and the Capacity to Produce}

As a necessary condition for dynamic capitalist expansion, the capacity to produce requires that the capitalist class invest their capital in economically productive activity. To what extent has financialization disconnected the accumulation of profit from capital investment thus undermining economic growth and expansion? There is growing evidence on the negative relationship between financialization and economic growth.

As outlined by Palley (2008: 2), "Financialization transforms the functioning of the economic system at both the macro and micro levels. Its principal impacts are to (1) elevate the significance of the financial sector relative to the real sector; (2) transfer income from the real sector to the financial sector". Harvey (2018: 20) frames the issue in terms of "paths of value in motion" and notes that

capital as value in motion loses its simple singular structure and shatters into component streams that often move in an antagonistic relation to each other [...] In recent times, for example, capital flow has tended to 


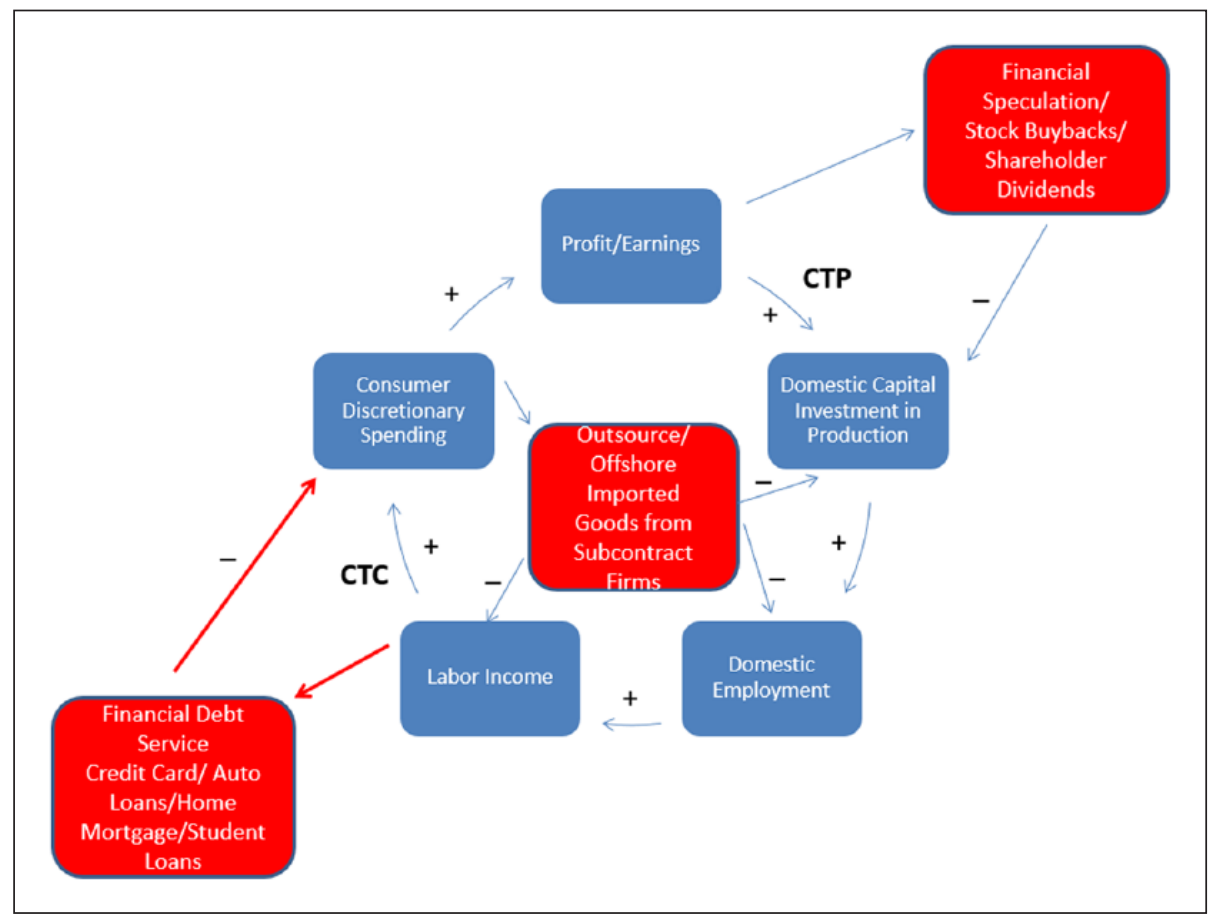

Figure 2. Financialization, corporate restructuring, and economic stagnation.

diminish with respect to value production while money capital seeks higher rates of monetary return elsewhere $[\ldots]$ the effect is to exacerbate the long run stagnation in value production.

Support for this general pattern is provided by the empirical analyses of Cecchetti and Kharroubi (2015: 20) who conclude that

the growth of a country's financial system is a drag on productivity growth [...] financial booms are not, in general, growth enhancing, probably because the financial sector competes with the rest of the economy for resources. Second, using sectoral data, we examine the distributional nature of this effect and find that credit booms harm what we normally think of as the engines for growth: those that are more R\&D-intensive.

More broadly, Stockhammer's $(2004,2010)$ studies of various advanced capitalist economies conclude that the "finance-dominated accumulation regime has been characterized by a sluggish overall economic performance with increasing financial fragility due to rising debt levels" (2010:9) and that "Financialization therefore can potentially explain an economically significant part of the slowdown in accumulation" (2004: 22).

While there is an obvious role for the financial sector in providing the liquid resources for the investment necessary for capital accumulation and expansion, the financialization thesis advanced here, and paralleling a model of disarticulation, suggests that the financial sector has become hypertrophied in relation to other sectors - that is, excessively and disproportionately large. Law and Singh (2014: 43) have provided evidence for a non-linear relationship between finance and economic growth. Based on time series data for a large number of countries, they identify a threshold effect for the "finance-growth nexus." More specifically, 
For financial development below the threshold, finance will exert a positive effect on economic growth. This implies that economic growth will be increased when financial development improves. On the other hand, if the financial development exceeds the threshold, the impact of finance on growth will turn negative suggesting that further financial development will not translate into higher economic growth [...] The empirical findings suggest that more finance is definitely not always better and it tends to harm economic growth after a point [...] In terms of policy implications, policy makers could focus less on increasing the size of the financial sector and more on improving its intermediating function. (Law and Singh, 2014: 43)

This pattern is further supported by Arcand et al. (2015: 23) who conclude that

there is a positive and robust correlation between financial depth and economic growth in countries with small and intermediate financial sectors, but we also show that there is a threshold (which we estimate to be at around $80-100 \%$ of GDP) above which finance starts having a negative effect on economic growth.

Firm-level studies confirm the general pattern that has been reported for the cross-national data. Orhangazi's (2008: 882-83) analysis for a sample of non-financial corporations from 1973 to 2003 finds

two aspects of financialisation could have negative effects on real capital accumulation. First, increased financial investments can crowd out real investment by directing funds away from real investment into financial investment and increased financial profits can change the incentives of the firm management regarding investment decisions. [...] Second, increased financial payments can decrease the funds available for real capital accumulation while the need to increase financial payments can decrease the amount of available funds, shorten the managerial planning horizon and increase uncertainty.

The diversionary impact of financialization must also be seen in light of the outsourcing/offshoring of production that further severs the connection between capital resources and "real investment" in the "real economy." As vertical disintegration has decoupled lead firms in production networks from all but the essential core competencies, profits are directed toward dividends, stock buybacks, and financial investment instruments rather than production which has now been outsourced to subcontractors. Milberg and Winkler's (2010: 290) empirical analysis of manufacturing and service sector firms indicates that

offshoring in the U.S. did raise the share of profits in income, but that the gains from offshoring have likely not been fully realised because firms have purchased financial assets rather than investing in productive assets that raise productivity, growth, employment and income. The financialisation of non-financial firms is a leakage from the system, which reduces the dynamic gains from offshoring by reducing reinvestment out of profits.

The economic impact of the diverted capital investment and subsequent slow growth has unequal distributional effects as reported in research by Tomaskovic-Devey et al. (2015: 17):

The shifting of non-financial firms' investment toward financial instruments and away from production decreased total value added in the non-finance economy [...] This negative effect on total production is visited on labor and the state as lower total income. The hypothesis that financialization of the non-finance sector reduces overall economic growth is supported by these analyses, but capital both as equity and debt holders were shielded from these negative consequences.

The dynamic described and informed by the analysis here would predict and accelerate the very process generating long-term trends toward inequality advanced by Piketty (2014) based on the differential returns to capital/wealth and income/growth. 


\section{Disarticulation and the Capacity to Consume}

As a second necessary condition for dynamic capitalist expansion, the capacity to consume requires that there be sufficient and widespread demand for the commodities produced in order for the capitalist class to realize profit. To what extent has financialization and corporate restructuring undermined wage growth and reduced disposable income available for consuming activities? The core problem here is the inability of the majority of workers to sustain patterns of consumption with earned income. As a result of the host of neoliberal policies aimed at weakening the power of labor and reducing labor's share of income, along with the slow growth generated by the diversion of capital investment noted above, a demand-side crisis is inevitable. It is here where financialization plays a dual and seemingly contradictory role. On the one hand, finance props up consumer demand in the form of what Crouch (2009) described as "privatized Keynesianism"; on the other hand, the accumulated debt becomes a drain on and diversion from future disposable income. Hudson (2016: 161-71) describes the two phases, in slightly different terms, as first "asset-price inflation" followed inevitably by "debt deflation." As the latter pertains to the capacity to consume, Hudson (2016: 160) writes "At some point repayment time arrives. Paying off debts absorbs income that otherwise would be available for spending on the goods and services that labor produces. This is the Debt Deflation stage. Each business upswing leaves a higher level of debt, diverting a rising proportion of income to pay debt service."

Or, as Dutt (2006: 361-62) formulates the problem, "However, in the longer run the effects of increasing consumer borrowing are ambiguous because, by increasing consumer debt, it redistributes income towards the rich who have a higher propensity to save, thereby possibly depressing aggregate demand and growth despite the borrowing-induced expansion". This same dynamic is examined by Setterfield and Kim (2016; see also Barba and Pivettit, 2008) who model economic growth based on the borrowing and consumption tendencies of workers seeking to emulate higher social classes. They conclude that consumption and debt servicing behavior has the effect of depressing aggregate demand, profitability, and economic growth rendering the neoliberal growth model unsustainable.

A recent report by the International Monetary Fund (2017: Chapter 2) devotes an entire chapter to "Household Debt and Financial Stability" noting the short- versus long-term effects: "Changes in household debt have a positive contemporaneous relationship to real GDP growth and a negative association with future real GDP growth" and that "household debt is correlated with future declines in private consumption" (2017: 62-63). In outlining the policy implications, the IMF sees the macroeconomic risk associated with household debt potentially mitigated in countries "that have better financial sector regulations and policies, and that have lower income inequality. Thus, even in countries where the level of household debt to GDP is high, the stability-growth trade-off can be attenuated by a combination of good policies, institutions, and regulations [...] and advancing policies that help reduce income inequality" including consumer financial protection (2017: 70-71). Unfortunately, past and continuing neoliberal policies in the United States actively militate against (e.g. repeal of the modest regulatory apparatus under Dodd-Frank) the policies prescribed by the IMF.

Meanwhile, according to the most recent figures reported by the Federal Reserve Bank of New York (2017), household debt has reached a record high of \$12.96 trillion, \$280 billion higher than the prior peak in 2008. There are several ways the rising debt can impact the capacity to consume. The most obvious and direct is simply as monthly deductions of interest payments from income. Second, consumers may begin to pull back from consumption where they believe they need to control the rise of debt, or pay down debt obligations. Third, rising levels of debt will impact the credit worthiness of consumers and make it more difficult to borrow for consumption into the future. 
There are several studies examining the relationship between consumer spending and accumulated debt, or household balance sheets, that suggest how the capacity to consume is negatively impacted with macroeconomic consequences. Dynan (2012), for example, uses household data from the Panel Study of Income Dynamics to determine whether the most heavily mortgage-leveraged households have reduced consumer spending. She concludes that for those households "with considerable debt overhangs in the form of elevated mortgage debt-to-asset ratios [...] spending of such households has been especially weak - more so than would be expected based on other factors affecting them, including the decline in wealth they experienced" (2012: 340). Others have suggested consumer spending cannot have the same impact on economic growth that it had in the past and one important reason is that "the loss of significant amounts of wealth and the severe pressure in some households to deleverage their balance sheets (reduce debt) are likely to contribute to restrained consumer spending for some time" (Emmons, 2012: n.p.). Mian et al. (2013) find declines in consumption associated with higher loan-to-value ratios, while Baker (2014) reports debt-to-asset ratios accounting for a significant drop in household consumption during the financial recession.

But even if consumer spending was continually robust, and financed on earnings rather than debt, the outsourcing/offshoring dimension of the globalized neoliberal model ensures disarticulation between consumer spending and domestic production. That is, the potentially positive effects of consumer spending on manufacturing of goods is felt largely abroad where the products are produced. This leaves the domestic stimulative employment effects confined primarily to retail and service sectors, along with transportation and logistics. Because these are not, on average, high wage sectors they do not contribute to significant wage growth. These structural features of the economy have been operating since the early 2000s with projection for consumer expenditure impact on economic sectors reporting that apart from agriculture, fisheries, and forestry, "Every other industry in the goods-producing sector is projected to have negative employment growth, despite consistent increases in consumer spending over the projection horizon" (Toossi, 2002: 17). A parallel analysis conducted in 2014 echoed these projections: "Focusing on consumer-related employment, we see that the Bureau projects employment to decline in goods-producing industries - mostly manufacturing - even though BLS [Bureau of Labor Statistics] anticipates more consumer demand for U.S.-made goods [...] The services sector is expected to account for virtually all consumer-related employment gains between 2012 and 2022” (Barello, 2014: n.p.).

Current consumer spending, and the record household debt levels, are accompanied by the largest trade deficit since 2008. This points to the fact that while the demand for commodities may be felt domestically at the retail merchant level, much of the potentially positive impact is absorbed abroad where the goods are actually produced and manufactured. This is a further form of disarticulation in terms of the impact of consumer demand on the domestic economy and sustained economic expansion.

Taken together, the short-circuiting of both the capacity to produce and the capacity to consume, stemming from two structural features of the neoliberal political economy - corporate restructuring and financialization - have contributed to the contemporary economic stagnating tendencies of the U.S. capitalist economy. While describing Figure 2 above as an "economic death spiral" might be engaging in hyperbole, observers across the political spectrum have predicted either some version of sustained or secular stagnation (e.g. Gordon, 2016; Summers, 2014) or, more apocalyptically, the end of capitalism as we know it (Mason, 2015; Streeck, 2016). I have attempted here to offer one framework within which to explain this widely acknowledged state of economic stagnation.

But these speculative scenarios are based largely on the state of the U.S. economy. What are the broader implications for the global capitalist economy if these trends continue? On the one hand, the stagnation of the U.S. economy, and the associated impact on the capacity consume, will 
continue to impact production levels in offshore locations, notably China, that have depended heavily on U.S. consumer spending. While this may produce economic disruption in the short-run, it may accelerate the Chinese shift toward a more "autocentric" or Keynesian capitalist model that is driven by higher wages and the consumer demand of the domestic population. Accordingly, this may contribute to the shifting balance of global leadership toward the Chinese economy and its particular trajectory of capitalist development.

\section{Conclusion - Potential Remedies and Prospects}

This paper has outlined the way in which neoliberal political economic policies have created structural conditions - most notably financialization and corporate global value chains - that have undermined the virtuous cycle of domestic capitalist growth and accumulation. Applying Amin's concept of disarticulation, we see today in the United States what he described for the less developed peripheral nations - weak and missing links, and diversions of capital, that short-circuit the capacities to produce and consume necessary for sustained economic growth.

It is difficult to imagine any simple solutions to these deep-seated structural maladies that are reinforced by an equally entrenched neoliberal ideology. Further, the distribution of costs and benefits from this disarticulated arrangement ensure that those most able to alter the patterns are the least likely to suggest an alternative political economic regime. Nonetheless, it is worth considering what two of the leading analysts of the macroeconomic consequences of neoliberalism, cited above, have suggested as needed reforms to address the obviously unsatisfactory economic performance of the U.S. economy as they relate to financialization and the operation of the private corporation.

Multiple analyses of the macroeconomic dynamics of financialization have led Palley (2008) to a series of policy recommendations. To reign in rampant financial speculation, he proposes greater regulation of the financial sector through asset-based reserve requirements. To impact corporate behavior, he emphasizes addressing the misalignment of incentives so that managers are accountable to a greater range of stakeholders beyond the immediate shareholders and money managers.

Lazonick (2011, 2013a, 2013b) has written extensively on the dysfunctional consequences of the "new business model" under the neoliberal political-economic regime, and the need to resuscitate the "innovative enterprise." To facilitate this organizational form, Lazonick (2011) proposes three "social conditions" - strategic control, organizational integration, and financial commitment. Strategic control requires that knowledgeable managers can make decisions that will enhance the innovative capabilities of the firm along with incentives that align with such productive investment decisions. In theory this would redirect the capacity to produce toward the reinvestment of profits into firm-level, rather than financial, assets. Organizational integration would strengthen relations among the firm's primary stakeholders - managers and workers - through incentives, compensation, and intrafirm human capital investment that encourage collective organizational learning. Ideally, with regard to the capacity to consume, this would provide levels of compensation to organizationally integrated employees reducing the reliance on debt-driven consumption. Finally, financial commitment would reinforce effective strategic control, promoting the "patient capital" required for long-term sustained innovation in product and process technologies.

These innovative enterprise social conditions would be supported by several larger policy reforms. These include banning stock repurchases so that the financial resources are directed toward the innovative organizational activities; indexing employee stock options to measures of innovative performance rather than stock-price; regulating the employment contract to share rewards with workers who contribute to the innovation processes; creating opportunities for the continuing productive use of educated and experienced workers; implementing taxes on the gains 
from innovation that can then be used as a public source of investment to sustain the human and technological infrastructure on which the innovative enterprise depends.

Both Palley and Lazonick are cognizant of the deeper ideological and political hurdles facing the policies they recommend. For Lazonick, (2013b: 907) this involves the "shareholder value model":

It will be very difficult to justify these reforms if Americans do not question the ideology that companies should be run to "maximize shareholder value". It is an ideology that results in inequity and instability and that ultimately undermines the productive foundations of economic growth. While MSV ideology has currency throughout the world, its pervasive and unquestioned acceptance has become an almost uniquely American phenomenon. The United States is engaged in global competition with highly innovative national economies in which MSV ideology does not hold sway. As long as this destructive ideology governs U.S. corporate resource allocation, the U.S. economy will remain incapable of generating middleclass jobs on the scale that is needed to restore sustainable prosperity.

For Palley (2008: 25) the political forces must be confronted:

In particular, there is need to address the political power of financial and non-financial corporations, as well as wealthy individuals. Addressing this problem will require tackling issues of lobbying and the influence of wealth on politics. It also concerns the way the democratic political process is organized. That includes disclosure requirements for politicians. It also may require changing the rules of elections, perhaps replacing current "winner take all" arrangements with forms of proportional representation that can give greater voice to those without resources. The reality is that economic power affects politics, and politics affects economic policy and economic outcomes, in turn impacting economic power. That means politics and economic policy need to be linked, rather than being seen as independent spheres as has historically been the case.

Currently in the U.S., there is little indication that either the ideological underpinnings or political powers that promote neoliberal policy, and its structural consequences, are in any danger of being overturned. In fact, the screws of neoliberalism are being tightened further under the Trump regime in spite of growing questions about the legitimacy of the neoliberal model. This leads one to consider the alternative route to transformation - continuing and deepening political-economic crises and contradictions that will necessitate structural transformation in order to salvage the capitalist edifice. One would have thought that the time had come with the great financial crisis of 2008, but as many have noted, and tried to understand and explain (e.g. Cahill, 2011; Mirowski, 2013; Streeck, 2016; Wolfson \& Kotz, 2010), neoliberalism lives on, albeit in significantly delegitimated form.

One of the most glaring of the growing fissures under neoliberalism, highlighted in the analysis of Dumenil and Levy (2011), is the divorce between the U.S. upper class and the domestic economy - where the economic health of the former is largely disconnected from the stagnation of the latter. This can be considered an additional form of disarticulation, coming home to roost, as Dumenil and Levy associate the disconnection with peripheral economies: "What is really new in this pattern of events is not the disconnection itself. Many countries in the periphery are or have been ruled by upper classes or fractions of classes that are not committed to the progress of their own countries" (2011: 27). But in many ways, it is this disconnection that has given neoliberalism its long-term durability. If the upper classes were suffering along with the larger domestic economy, the class forces for structural transformation would be enhanced. Nonetheless, while the disconnection might partially explain the longevity of the neoliberal model, Dumenil and Levy (2011:29) suggest it is unsustainable and they speculate that it could be replaced by what they label 
"neomanagerial capitalism" involving a "much needed 'reconciliation' between the upper classes and the domestic economy." It would include less financial and more domestic capital investment, restrictions on trade and capital mobility, and a more tightly-regulated financial sector. This is a political-economic regime implementing some of the policy prescriptions outlined by Palley and Lazonick but would require "a compromise between the upper classes, capitalists and managers, but under managerial leadership, with a degree of containment of capitalist interests" (Dumenil and Levy, 2011: 29).

Among select segments of the capitalist class there appears to be some growing awareness of the dysfunctional aspects of U.S. capitalism. For example, 13 CEOs including Warren Buffett (Berkshire Hathaway Inc.) and Jamie Dimon (JP Morgan) signed on to a set of "Commonsense Corporate Governance Principles" (http://www.governanceprinciples.org). The "open letter" pointed to the need to reform corporate governance procedures away from the short-term shareholder value model with an emphasis on "companies being managed effectively for long-term prosperity" and fostering "economic growth that benefits shareholders, employees and the economy as a whole". This would represent a significant positive break from the current corporate governance regime associated with neoliberalism and align with some of the proposals outlined above. Another indication is the formation of the "American Made Coalition" that includes 25 major corporations including GE, Boeing, Dow Chemical, Eli Lilly, and Pfizer. The coalition has focused primarily on tax reform that would incentivize domestic production and disincentivize importation through, for example, a $20 \%$ border adjustment tax on imported goods.

It is not clear whether these developments represent a renewed effort by some segments of the capitalist class to organize and redirect political-economic policy toward a wider shared prosperity. If so, it would counter the larger state of affairs under neoliberalism carefully documented by Mizruchi (2013) who has offered the counterintuitive thesis that, contrary to what one might expect given capitalist class hegemony, the corporate elite today are highly fragmented and disorganized. He argues that: "This is an elite that, rather than leading, has retreated into narrow self-interest, its individual elements increasingly able to get what they want in the form of favors from the state but unable collectively to address any of the problems whose solution is necessary for their own survival" (Mizruchi, 2013: 265). Mizruchi's thesis is plausible given the steady decline of labor as a countervailing force thus allowing capital to "get what it wants" with minimal pushback or compromise and without the necessity of collective political organization. If, as some have argued (Hodgson, 2001; Streeck, 1997), the long-term viability of capitalism as a system is dependent upon oppositional pushback to prevent extreme and destructive excess, the road to political-economic transformation may be driven by a different dynamic as described by Streeck (2016: 58): "the stability of capitalism as a socioeconomic system depends on the Eigendynamik being contained by countervailing forces - by collective interests and institutions subjecting capital accumulation to checks and balances. The implication is that capitalism may undermine itself by being too successful."

\section{Funding}

This research received no specific grant from any funding agency in the public, commercial, or not-for-profit sectors.

\section{References}

Appelbaum E and Batt R (2014) Private Equity at Work: When Wall Street Manages Main Street. New York, NY: Russell Sage Foundation.

Amin S (1976) Unequal Development: An Essay on the Social Formations of Peripheral Capitalism. New York, NY: Monthly Review Press.

Arcand JL, Berkes E and Panizza U (2015) Too much finance? Journal of Economic Growth 20(2): 105-148. 
Baker SR (2014) Debt and the consumption response to household income shocks. SSRN Research Paper 2541142: 1-46.

Baran P and Sweezy P (1966) Monopoly Capitalism: An Essay on the American Economic and Social Order. New York, NY: Monthly Review Press.

Barba A and Pivetti M (2008) Rising household debt: Its causes and macroeconomic implications - a longperiod analysis. Cambridge Journal of Economics 33(1): 113-137.

Barello S (2014) Consumer spending and U.S. employment from the 2007-2009 recession through 2022. Monthly Labor Review, October. Washington, DC: U.S. Bureau of Labor Statistics. Available (accessed 4 September 2018) at: https://doi.org/10.21916/mlr.2014.34

Bowles S, Gordon DM and Weisskopf TE (1990) After the Waste Land: A Democratic Economics for the Year 2000. New York, NY: ME Sharpe.

Cahill D (2011) Beyond neoliberalism? Crisis and the prospects for progressive alternatives. New Political Science 33(4): 479-492.

Cecchetti SG and Kharroubi E (2015) Why does financial sector growth crowd out real economic growth? Available (accessed 4 September 2018) at: https://cdn.evbuc.com/eventlogos/67785745/cecchetti.pdf

Crouch C (2009) Privatised Keynesianism: An unacknowledged policy regime. The British Journal of Politics \& International Relations 11(3): 382-399.

Davis GF (2016) The Vanishing American Corporation: Navigating the Hazards of a New Economy. Oakland, CA: Berrett-Koehler Publishers.

De Janvry A (1981) The Agrarian Question and Reformism in Latin America. Baltimore, MD: Johns Hopkins University Press.

Dumenil G and Levy D (2011) The Crisis of Neoliberalism. Cambridge, MA: Harvard University Press.

Dutt AK (2006) Maturity, stagnation and consumer debt: A Steindlian approach. Metroeconomica 57(3): $339-364$.

Dynan K (2012) Is a household debt overhang holding back consumption? Brookings Papers on Economic Activity 2012(1): 299-362.

Emmons W (2012) Don't expect consumer spending to be the engine of economic growth it once was. Federal Reserve Bank of St. Louis, January. Available (accessed 4 September 2018) at: https://www.stlouisfed. org/publications/regional-economist/january-2012/dont-expect-consumer-spending-to-be-the-engineof-economic-growth-it-once-was

Federal Reserve Bank of New York (2017) Quarterly report on household debt and credit (Q3, November). Available (accessed 4 September 2018) at: https://www.newyorkfed.org/medialibrary/interactives/ householdcredit/data/pdf/HHDC_2017Q3.pdf

Fligstein N (1993) The Transformation of Corporate Control. Cambridge, MA: Harvard University Press.

Foster JB and McChesney RW (2012) The Endless Crisis: How Monopoly-finance Capital Produces Stagnation and Upheaval from the USA to China. New York, NY: NYU Press.

Gereffi G (1994) The organization of buyer-driven global commodity chains: How US retailers shape overseas production networks. In: Gereffi G and Korzeniewicz M (eds) Commodity Chains and Global Capitalism. Westport, CT: Greenwood Press, 95-122.

Gordon DM, Edwards R and Reich M (1982) Segmented Work, Divided Workers: The Historical Transformation of Labor in the United States. Chicago, IL: Chicago University Press.

Gordon RJ (2016) The Rise and Fall of American Growth: The U.S. Standard of Living Since the Civil War. Princeton, NJ: Princeton University Press.

Greenwood R and Scharfstein D (2013) The growth of finance. The Journal of Economic Perspectives 27(2): $3-28$.

Harding R (2013) Corporate investment: A mysterious divergence. Financial Times, 24 July. Available (accessed 4 September 2018) at: https://www.ft.com/content/8177af34-eb21-11e2-bfdb-00144feabdc0

Harvey D (1982) The Limits to Capital. Chicago, IL: University of Chicago Press.

Harvey D (2018) Marx, Capital, and the Madness of Economic Reason. New York, NY: Oxford University Press.

Hirschman AO (1958) The Strategy of Economic Development. New Haven, CT: Yale University Press. 
Hodgson GM (2001) The evolution of capitalism from the perspective of institutional and evolutionary economics. In: Hodgson GM (ed.) Capitalism in Evolution: Global Contentions-East and West. Cheltenham, UK: Edward Elgar Publishing, 63-82.

Hudson M (2016) Killing the Host: How Financial Parasites and Debt Bondage Destroy the Global Economy. New York, NY: ISLET.

International Monetary Fund (2017) Global Financial Stability Report October 2017: Is Growth at Risk? Available (accessed 4 September 2018) at: https://www.imf.org/en/Publications/GFSR/ Issues/2017/09/27/global-financial-stability-report-october-2017

Jaffee D (2001) Organization Theory: Tension and Change. New York, NY: McGraw-Hill.

Kaplinsky R and Morris M (2001) A Handbook for Value Chain Research (Vol. 113). Ottawa: IDRC.

Krippner GR (2005) The financialization of the American economy. Socio-economic Review 3(2): 173-208.

Krippner GR (2011) Capitalizing on Crisis. Cambridge, MA: Harvard University Press.

Law SH and Singh N (2014) Does too much finance harm economic growth? Journal of Banking \& Finance 41: 36-44.

Lazonick W (2011) The innovative enterprise and the developmental state: Toward an economics of "organizational success". Presented at Institute for New Economic Thinking Annual 2011 Conference, Bretton Woods, NH, 8-11 April 2011. Available (accessed 4 September 2018) at: https://www.ineteconomics. org/uploads/papers/BWpaper_LAZONICK_040811.pdf

Lazonick W (2013a) From innovation to financialization: How shareholder value ideology is destroying the U.S. economy. In: Wolfson MH and Epstein GA (eds) The Handbook of the Political Economy of Financial Crises. New York, NY: Oxford University Press, 491-511.

Lazonick W (2013b) The financialization of the U.S. corporation: What has been lost, and how it can be regained. Seattle University Law Review (36): 857-909.

Lazonick W (2014) Profits without prosperity. Harvard Business Review 92(9): 46-55.

Lazonick W and O'Sullivan M (2000) Maximizing shareholder value: A new ideology for corporate governance. Economy and Society 29(1): 13-35.

Lichtenstein N (2014) Two cheers for vertical integration: Corporate governance in a world of global supply chains. Unpublished manuscript, University of California-Santa Barbara, CA.

Marens R (2003) Two, three, many Enrons: American financial hypertrophy and the end of economic hegemony. Organization 10(3): 588-593.

Mason P (2015) Postcapitalism: A Guide to Our Future. New York, NY: Farrar, Straus and Giroux.

Mian A, Rao K and Sufi A (2013) Household balance sheets, consumption, and the economic slump. The Quarterly Journal of Economic 128(4): 1687-1726.

Milberg W and Winkler D (2010) Financialisation and the dynamics of offshoring in the USA. Cambridge Journal of Economics 34(2): 275-293.

Milberg W and Winkler D (2013) Outsourcing Economics: Global Value Chains in Capitalist Development. New York, NY: Cambridge University Press.

Mirowski P (2013) Never Let a Serious Crisis Go to Waste: How Neoliberalism Survived the Financial Meltdown. New York, NY: Verso Books.

Mizruchi MS (2013) The Fracturing of the American Corporate Elite. Cambridge, MA: Harvard University Press.

Orhangazi Ö (2008) Financialisation and capital accumulation in the non-financial corporate sector: A theoretical and empirical investigation on the U.S. economy: 1973-2003. Cambridge Journal of Economics 32(6): 863-886.

Palley T (2008) Financialization: What it is and why it matters (IMK Working Paper, No. 04/2008). Available (accessed 7 August 2018) at: https://www.econstor.eu/bitstream/10419/105902/1/imk-wp_2008-04.pdf

Piketty T (2014) Capital in the Twenty-First Centiry. Cambridge, MA: Belknap.

Setterfield M and Kim YK (2016) Debt servicing, aggregate consumption, and growth. Structural Change and Economic Dynamics 36: 22-33.

Stockhammer E (2004) Financialisation and the slowdown of accumulation. Cambridge Journal of Economics 28(5): 719-741. 
Stockhammer E (2010) Financialization and the global economy. Political Economy Research Institute Working Paper, 242. Available (accessed 7 August 2018) at: https://www.peri.umass.edu/fileadmin/pdf/ working_papers/working_papers_201-250/WP240.pdf

Streeck W (1997) Beneficial constraints: On the economic limits of rational voluntarism. In: Hollingworth JR and Boyer R (eds) Contemporary Capitalism: The Embeddedness of Institutions. New York, NY: Cambridge University Press, 197-219.

Streeck W (2016) How will capitalism end? New York, NY: Verso.

Summers LH (2014) U.S. economic prospects: Secular stagnation, hysteresis, and the zero lower bound. Business Economics 49(2): 65-73.

Tomaskovic-Devey D, Lin KH and Meyers N (2015) Did financialization reduce economic growth? SocioEconomic Review 13(3): 525-548.

Toossi M (2002) Consumer spending: An engine of U.S. job growth. Monthly Labor Review, November. Washington, DC: U.S. Bureau of Labor Statistics. Available (accessed 10 July 2018) at: https://www. bls.gov/opub/mlr/2002/11/art2full.pdf

Weil D (2014) The Fissured Workplace: Why Work Became So Bad For So Many and What Can Be Done to Improve It. Cambridge, MA: Harvard University Press.

Wolfson MH and Kotz DM (2010) A reconceptualization of social structure of accumulation theory. In: Kotz DM and Reich M (eds) Contemporary Capitalism and its Crises: Social Structure of Accumulation Theory for the 21st Century. New York, NY: Cambridge University Press, 72-90. 